\title{
Studies on the Development of Hybrid Agrofibre Reinforced Biocomposites
}

\author{
Anda Dzene ${ }^{1}$, Velta Tupureina ${ }^{2}$, Marcis Dzenis ${ }^{3}$, \\ ${ }^{1-3}$ Riga Technical University
}

\begin{abstract}
The main goal of the presented study is the development of two agrofibres - hemp/flax and hemp/hemp shive reinforced hybrid biocomposites based on waterborne polymer matrix system - blends of biodegradable polyhydroxybutyrate (PHB) and poly(vinyl alcohol) (PVA). The correlation between agrofibre ratio and mechanical characteristics of hybrid agrofibre reinforced biocomposites has been established. The positive hybrid effect and optimal results in terms of mechanical strength of hemp/flax biocomposites have been found in $4: 1$ ratio. The elaborated hybrid biocomposites are considered biodegradable in soil, their mass loss is found to be $\geq 52 \% \ldots 54 \%$ from initial mass during 5 months.
\end{abstract}

Keywords - Agrofibres, flax, hemp, hemp shive, hybrid biocomposites, waterborne matrix.

\section{INTRODUCTION}

The growing environmental and economic pressure is the reason to search for environmentally friendly materials from renewable resources. Hence, the employment of natural agrofibres as reinforcement for biocomposites seems to be a good potential for use in waste management due to their biodegradability, renewability and characteristics peculiar to these systems [1]. The adaptation of biodegradable polymers as a suitable matrix for agrofibre application can produce novel biocomposites to replace glass fibre - reinforced composites and the challenge is to design materials that exhibit structural and functional stability during storage and use, yet are susceptible to microbial and environmental degradation upon disposal, with no adverse environmental impact [2].

Specific kinds of fibre reinforced composites are hybrid composites containing two or more types of different fibres and providing a favorable balance between the inherent properties of components [3-6]. Such composites offer range of properties that cannot be obtained with single kind of reinforcement. Hybrid composites can be designed by the combination of synthetic and natural fibres in a matrix or a combination of two natural/bio-fibres in a matrix; however, hybrid composites containing natural fibres are less studied [4].

The main goals of the present study are the development of two agrofibres - hemp/flax - reinforced hybrid composites based on waterborne biodegradable polymer matrix systems blends of polyhydroxybutyrate (PHB) and poly(vinyl alcohol) (PVA) - and the assessment of their characteristics.

\section{MATERIALS AND METHODS}

Matrix materials used were as follows:

PHB powder from "Biomer®" (Germany) - M.w. 540 kDa, $\mathrm{T}_{\mathrm{m}}=176^{\circ} \mathrm{C}$, degree of crystallinity $61 \%$, density $1.25 \mathrm{~g} / \mathrm{cm}^{3}$; PHB latex - the aqueous suspension of colloidal PHB native granules prepared at the University of Latvia (LU MBI) from microbially synthesized PHB (Azotobacter chroococuum 23) biomass (optimal concentration in the range of 170-200 g/l, $\left.\mathrm{T}_{\mathrm{m}}=177^{\circ} \mathrm{C}\right)$.

PVA - partially crystalline, water soluble, M.w. $131 \mathrm{kDa}$, $98.0 \%$... 99.2 \% hydrolyzed and plasticized with glycerol (G).

Reinforcement - two agrofibres: industrial hemp (K) and hemp shive $\left(\mathrm{K}_{\mathrm{s}}\right)$ - Bialobrezskie (Poland brand, cultivated in Latvia); flax fibre (F) used was flax combing from factory LareLini (Latvia). All fibres were chopped by Retsch Ultra Centrifugal Mill into lengths of $\leq 3 \mathrm{~mm}$.

The formation process of reinforced biocomposites was performed by a solution casting technique based on the socalled "wet process", i.e., incorporating fibres by blending in a high-intensity mixer with subsequent drying and compression moulding [7].

Mechanical characteristics of biocomposites were determined by ZwickRoell Testing machine in accordance with LVS EN ISO 527-3. Laboratory accelerated soil degradation tests were carried out gravimetrically at $25{ }^{\circ} \mathrm{C}$ in the microbially active garden soil.

\section{RESULTS AND DISCUSSION}

The corrected formation process of some reinforced hybrid biocomposites was developed including a preliminary step of mixing of two agrofibres (hemp/flax; hemp/hemp shive) in comminutor (PT-1) before incorporating such a blend of the fibres in the prepared matrix dispersion in accordance with [7].

The effect of agrofibre ratio and matrix composition on the changes of mechanical characteristics of hybrid biocomposites has been evaluated with reference to the relative volume fraction of two fibres at a constant total loading of 0.3 volume fraction (Fig. 1) which was optimized earlier [7].

It has been ascertained that the mechanical characteristics of the obtained hybrid composites are dependent upon the properties and reciprocal relations of the fibres used, the values of tensile strength of hybrid composites increase at higher hemp fibre content. Optimal results in terms of mechanical strength of the hemp/flax hybrid composites were ensured in a ratio of $4: 1$. 


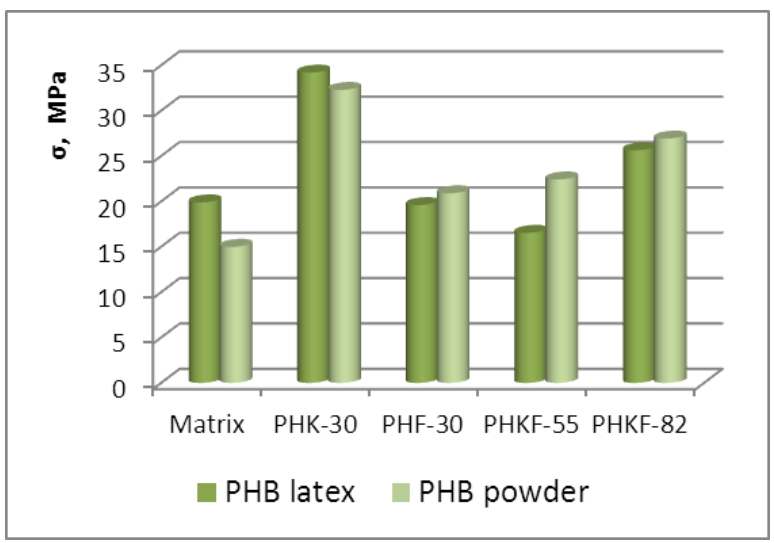

Fig. 1. Mechanical characteristics of hemp/flax reinforced biocomposites: designations of biocomposites are decoded in Table 1 .

As presented in $[3,4]$, the specific rule of mixtures offers the possibility of evaluating the mechanical behavior of hybrid systems, and such a rule has been widely used to predict the strength and modulus, etc. of hybrid composites.

The rule of mixtures has been used as follows [3]:

$$
\mathrm{P}_{\mathrm{H}}=\mathrm{P}_{1} \mathrm{~V}_{1}+\mathrm{P}_{2} \mathrm{~V}_{2}
$$

where $P_{H}$ is the property to be investigated, $P_{1}-$ the corresponding property of the first system and $\mathrm{P}_{2}-$ the corresponding property of the second system. $\mathrm{V}_{1}$ and $\mathrm{V}_{2}$ are the relative hybrid volume fractions of the first and second systems and $\mathrm{V}_{1}+\mathrm{V}_{2}=1$.

The adaptation of such a rule of mixtures for comparison of the experimental and predicted results of mechanical characteristics of the obtained agrofibre reinforced hybrid biocomposites has been verified. Table 1 and Fig. 1 present tensile strength $\left(\sigma_{\mathrm{T}}\right)$, elongation $(\varepsilon)$ and modulus $\left(\mathbf{E}_{\mathrm{T}}\right)$ values of various biocomposite formulations.

The obtained results testify that predicted $\sigma_{\mathrm{T}}$ results of hybrid biocomposites are somewhat higher but very close to those obtained experimentally. It has been ascertained that the difference between predicted and experimental values of $\sigma_{\mathrm{T}}$ for hemp/flax biocomposites is smaller at the higher hemp content (Fig. 2).

\section{TABLE 1}

Hybrid EFFECTS OF AGROFIBRE REINFORCED BIOCOMPOSITES

\begin{tabular}{|l|c|c|c|c|c|c|}
\hline \multirow{2}{*}{ Biocomposite } & \multicolumn{2}{|c|}{$\boldsymbol{\sigma}_{\mathrm{T}}, \mathrm{MPa}$} & \multicolumn{2}{c|}{$\mathbf{E}_{\mathrm{T}}, \mathrm{Mpa}$} & \multicolumn{2}{c|}{$\boldsymbol{\varepsilon}_{\mathrm{T}}, \%$} \\
\cline { 2 - 7 } & Exp. & Pred. & Exp. & Pred. & Exp. & Pred. \\
\hline PHF-30 & 20.9 & & 309 & & 11.0 & \\
\hline PHK-30 & 32.3 & & 739 & & 7.9 & \\
\hline PHK $_{\mathrm{s}}-30$ & 13.2 & & - & & 5.7 & \\
\hline PHKF-55 & 24.4 & 26.6 & 550 & 524 & 8.3 & 9.5 \\
\hline PHKF-82 & 29.2 & 30.0 & 650 & 653 & 8.6 & 8.5 \\
\hline PHKK $_{\mathrm{s}}-82$ & 28.8 & 28.5 & 772 & & 7.1 & 7.5 \\
\hline
\end{tabular}

Designations of biocomposites:

matrix weight ratio: 1.0 PVA:0.3 G:0.5 PHB $(\mathrm{PH})$; fibre length $<3 \mathrm{~mm}$; 30 - common fibre content; $\mathrm{F}$ - flax; $\mathrm{K}$ - hemp; $\mathrm{K}_{\mathrm{s}}$ - hemp-shives; fibres ratio: $55=1: 1 ; 82=4: 1$.

The positive hybrid effect that is defined as positive deviation of a certain mechanical property [3] has been found for $\mathbf{E}_{\mathrm{T}}$ and
$\boldsymbol{\varepsilon}_{\mathrm{T}}$ values of the hemp/flax and hemp/hemp shive hybrid biocomposites in a ratio of $4: 1$.

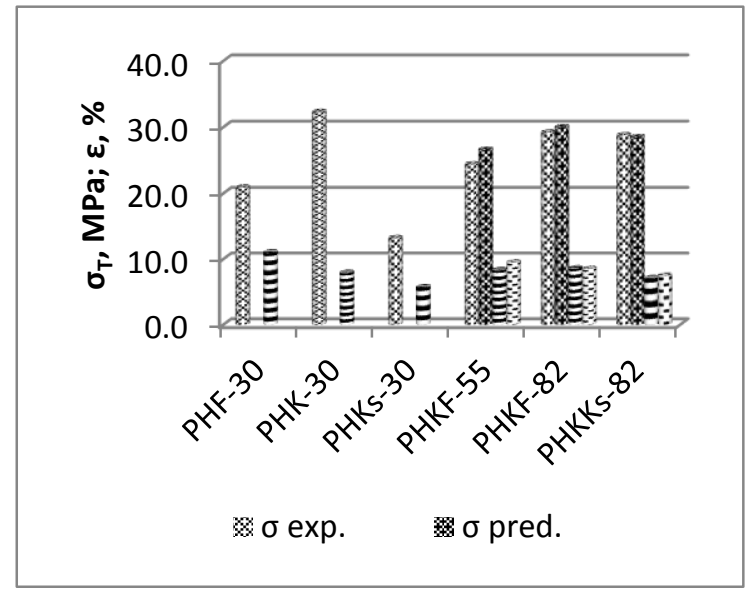

Fig.2. The comparison of experimental and predicted $\sigma_{t}$ and $\varepsilon$ values of various compositions of biocomposites.

The summarized first results of some tested agrofibre reinforced hybrid biocomposites confirm efficiency of using such a simple rule of mixtures as a rapid means for evaluation and prediction of the main deformative characteristics of the obtained hybrid biocomposites, and such an approach needs to be studied in detail for various agrofibre reinforced biocomposites of increased variety.

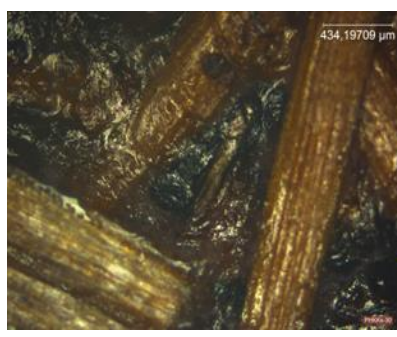

a)

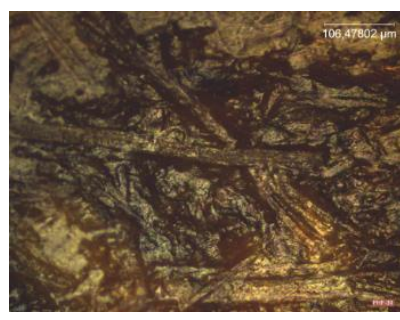

c)

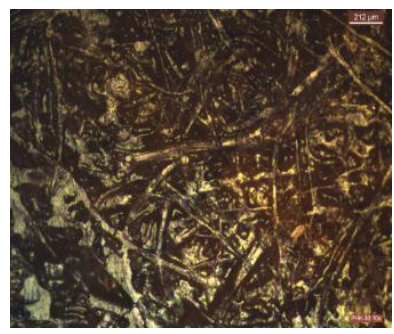

b)

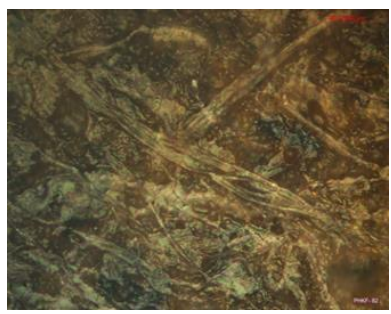

d)

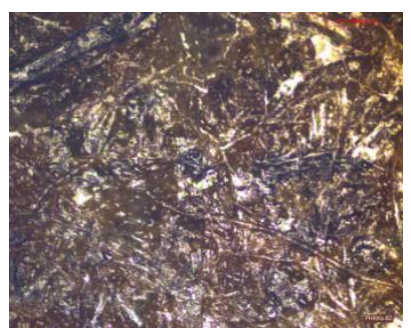

e)

Fig. 3. Optical micrographs of the single agrofibres $(a ; b ; c)$ and hybrid agrofibres (d; e) reinforced biocomposites: $\mathrm{a}-\mathrm{PHK}_{\mathrm{s}}-30$; $\mathrm{b}-\mathrm{PHK}-30$; c - PHF-30; d - PHKF-82; e - $\mathrm{PHKK}_{\mathrm{s}}-82$. Magnification: a) $5 \mathrm{x}$; b) ...e) $10 \mathrm{x}$ 
The morphology of the hybrid agrofibre reinforced composites has been estimated by optical microscope Leica DMRM showing the state and quality of fibre dispersion (Fig. 3).

The comparison of micrographs of biocomposites containing single fibre reinforcement (only flax, hemp, hemp shive) with their combination in hybrid composites shows miscibility of fibres to a certain extent and comperatively equable distribution of hybrid fibres in the biocomposites. Some heterogeneity of fibre distribution has been revealed indicating to the imperfect bonding between fibres and matrix which needs to be further optimized through the modification of matrix - reinforcement interface.

The elaborated hybrid agrofibre reinforced biocomposites could be considered biodegradable in soil because accelerated soil degradation tests revealed $\geq 52 \%$.. $54 \%$ mass loss from initial mass during 5 months.

\section{CONCLUSIONS}

The corrected formation process of the hybrid agrofibre (hemp, hemp shive, flax) reinforced biocomposites based on aqueous systems of biodegradable polymers as a continuous matrix has been developed.

The correlation between agrofibre ratio and mechanical characteristics of the hybrid agrofibre reinforced biocomposites has been established. The optimal results in terms of mechanical strength of hemp/flax and hemp/hemp shive reinforced hybrid composites have been obtained in a ratio of $4: 1$. The complete use of all components of hemp plant has been ascertained with partial substitution of the hemp fibre by hemp shive in the composition of the reinforced hybrid composites ensuring sufficiently high mechanical characteristics.

The adaptation of the rule of mixtures for prediction of the mechanical characteristics of the elaborated hybrid agrofibre reinforced biocomposites has been accepted and a positive hybrid effect has been found for $\mathbf{E}_{\mathrm{T}}$ values of hemp/flax and hemp/hemp shive hybrid biocomposites. All elaborated hybrid biocomposites have been found as biodegradable in soil, their mass loss achieved $\geq 52 \%$.. $54 \%$ from initial mass.

\section{ACKNOWLEDGEMENTS}

The study was supported by the Latvian Council of Science, Cooperation Project No. 10.0040.

\section{REFERENCES}

[1] Yu L., Dean K., Li L. Polymer Blends and Composites from Renewable Resources. Prog. Polym. Sci., 2006, vol. 31, pp. 576-602. http://dx.doi.org/10.1016/j.progpolymsci.2006.03.002

[2] Mohanty A.K., Misra M., Drzal L.T. Sustainable Bio-Composites from Renewable Resources: Opportunities and Challenges in the Green Materials World. Journal of Polymers and the Environment, 2002, vol. 10, N 1/2, April, pp. 19-26. http://dx.doi.org/10.1023/A:1021013921916

[3] John M.J., Thomas S. Biofibers and biocomposites. Carbohydrate Polymers, 2008, vol. 71, pp. 343-364. http://dx.doi.org/10.1016/j.carbpol.2007.05.040

[4] Mirhagheri J., Tajvidi M., Hermanson J.C., Ghasemi I. Tensile Properties of Wood Flour/kenaf Fiber Polypropylene Hybrid Composites. J.Appl.Polymer Science, 2007, vol. 105, pp. 3054-3059. http://dx.doi.org/10.1002/app.26363

[5] Idicula M., Neelakantan N.R., Oommen Z., Joseph K., Thomas S. A study of the mechanical properties of randomly oriented short banana and sisal hybrid fiber reinforced polyester composites. J. Appl. Polymer Science, 2005, vol. 96, pp. 1699-1709. http://dx.doi.org/10.1002/app.21636

[6] Jacob M., Thomas S., Varughese K.T. Biodegradability and aging studies of hybrid biofiber reinforced natural rubber biocomposites.

[7] J. Biobased Materials and Bioenergy, 2007, vol. 1, No. 1, pp. 118-126.

[8] Laiveniece L., Tupureina V., Dzene A. Hemp fiber reinforced biocomposites. In: $3^{\text {rd }}$ International Conference on Innovative Natural Fiber Composites for Industrial Applications, Rome, Italy, October 12-14, 2011. Abstract. CD.

Anda Dzene, Dipl. ing., Researcher at Riga Technical University. A.Dzene graduated from Riga Polytechnical Institute in 1961 and received Dipl.ing. degree in Chemical Technology. Since 1965, A.Dzene has been working at Riga Technical University. Since 2007, she has been a Researcher at the Institute of Polymer Materials (Faculty of Material Science and Applied Chemistry). Research interests: biopolymers, technology of modified biodegradable biocomposites. The results of the research have been approbated in more than 30 scientific publications, 3 Latvian patents and reports in $\sim 15$ international scientific conferences.

Address: Azenes Str. 14/24, LV 1048, Riga, Latvia

E-mail: anda.jugla@inbox.lv

Velta Tupureina, M. sc. ing., Researcher at Riga Technical University, Faculty of Material Science and Applied Chemistry, Institute of Polymer Materials. She is the author of more than 200 scientific publications in the branch of polymer chemistry and technology. Main scientific interests are related to biodegradable polymers and their modified and reinforced systems. Main elaborated biodegradable polymer systems are protected by 3 patents of Latvia.

Address: Azenes Str. 14/24, LV 1048, Riga, Latvia

Phone: + 37167089219 , Fax: + 37167615765

E-mail: velta.tupureina@rtu.lv

Marcis Dzenis, Dr. sc. ing., Riga Technical University. He is a Deputy Dean for Research of the Faculty of Material Science and Applied Chemistry, Associate Professor of the Institute of Polymer Materials. He graduated from Riga Polytechnical Institute in 1970 obtaining a qualification of a Chemical Technologist in polymer processing technology. Research interests: polymer coatings, adhesion, interface and boundary processes, ageing of materials, conservation and restoration of cultural heritage.

Address: Azenes Str. 14/24, Riga, LV-1048, Latvia

Phone: +371 67089220, Fax: + 37167615765

E-mail: marcis@ktf.rtu.lv

\section{Anda Dzene, Velta Tupureina, Mārcis Dzenis. Ar agrošķiedrām stiegrotu hibrīd-biokompozītu iegūšana un izpēte}

Attīstoties pētījumiem par dabai draudz̄igiem materiāliem, interesi piesaista ar agroškikedrām stiegrotu biokompozītu izstrāde, akcentējot bionoārdāmu polimērmatricu izmantošanu, lai veidotu kompozītmateriālus, kuri spēj saglabāt strukturālo un funkcionālo stabilitāti kalpošanas laikā, bet ir pakḷauti bionoārdīšanās procesiem pēc nonākšanas atkritumos. Pētījuma mērkis ir specifisku hibrīdkompozītu veidošana, izmantojot divu agrošķiedru - kaṇepāju/linu un kaṇepāju/kaṇepāju spaḷu - maisījumus kā stiegrojumu (ar kopējo stiegrojuma saturu 30 \%) bionoārdāmu polimēru - polihidroksibutirāta (PHB) un polivinilspirta (PVS) - sistēmu matricās. Precizēta iepriekš aprobēta hibrīdkompozītu izgatavošanas tehnoloǵija, disperğējot agrošķiedru maisījumu izvēlēto polimērmatricu ūdens sistēmās. Noskaidrota agrošķiedru veida un savstarpējo attiecību ietekme uz iegūto hibrīdkompozītu mehānisko stiprību. Optimālās stiprības vērtības nodrošina kaņepāju/linu attiecība 4:1. Daḷēja kaṇepāju škiiedras aizvietošana ar spaliem maisījumā paplašina vispusīgas auga komponentu izmantošanas iespējas, būtiski neietekmējot biokompozītu stiprības vērtības. Akceptēta maisījumu likuma piemērotība biokompozītu deformatīvo raksturojumu hibrīdefekta novērtēšanai. Pozitīvu hibrīdefektu nodrošina elastības moduḷa un stiepes stiprības vērtības sistēmās ar 80 \% kaṇepāju saturu agrošḳiedru maisījumā. Konstatēts, ka 
izveidotie hibrīdkompozīti ir augsnē bionoārdāmi, jo 5 mēnešu laikā tie zaudē vairāk par 55 \% no sākotnējās masas. Pašreizējā pētījumu stadijā iegūtie rezultāti liecina, ka izvēēêtais pētījumu virziens ir perspektīvs un nepieciešams paplašināt hibrīdkompozītu klāstu, kā arī pilnveidot pētījumu metodes.

Анда Дзене, Велта Тупурейна, Марцис Дзенис. Получение и исследование гибридных биокомпозитов, армированных натуральными волокнами

Благодаря развитию исследований в области дружественных природе материалов, интерес привлекает разработка биокомпозитов, армированных натуральными волокнами, акцентируя использование биоразлагающихся полимерных матриц для создания композиционных материалов, способных сохранять структурную и функциональную стабильность во время эксплуатации, но подвергающихся процессам биоразложения после попадания в отходы. Целью исследования является создание специфических гибридных композитов с использованием смесей двух природных волокон -конопля/лен и конопля/костра конопли в качестве арматуры (с общим содержанием волокон 30 \%) матриц - систем биоразлагающихся полимеров - полигидроксибутирата (ПГБ) и поливинилового спирта (ПВС). Уточнена ранее опробированная технология изготовления гибридных композитов диспергированием смеси природных волокон в водных системах выбранных полимерных матриц. Выяснено влияние вида и взаимных отношений природных волокон на механическую прочность полученных гибридных композитов. Оптимальные значения прочности обеспечивает соотношение конопля/лен 4:1. Частичная замена в смеси волокон конопли кострой расширяет возможность всестороннего использования компонентов растения, существенно не влияя на показатели прочности биокомпозитов. Акцептирована применимость закона смесей для оценки гибридного эффекта деформативных характеристик биокомпозитов. Положительный гибридный эффект обеспечивают показатели модуля эластичности и прочности при растяжении в системах с содержанием конопляного волокна 80 \% в смеси природных волокон. Установлено, что созданные гибридные композиты биологически разлагаются в почве, так как в течение 5 месяцев теряют $>55$ \% начального веса. Результаты, полученные на данной стадии изучения, свидетельствуют о перспективности выбранного направления и необходимости расширения набора гибридных композитов и усовершенствования методов исследования. 